\title{
Staff turnover as a kind of personnel risk In hotel enterprises in Poland
}

\author{
Anna Tokarz-Kocik \\ University of Szczecin (Poland), Institute of Management
}

\begin{abstract}
Staff turnover is the inflow and outflow of employees in an enterprise. Many enterprises have problems not only with finding suitable employees but also with retaining them. The objective of the article is to present an impact of staff turnover on the operation of hotel enterprises. Method: A theoretical part of the study is a result of the use of the desk research method. Unique entity's influence (i.e. hotel enterprise's personnel) and the executed processes of human resource management mean that human resource risk has to be assessed individually for each entity. Therefore, the author used case studies in the empirical part aiming at exemplifying human resource activities in the hotel industry. There are results from surveys and interviews with human resource managers conducted in 250 hotels in Poland. The presented research findings confirm that human resource activities in hotels are not always conducted properly. Instead of making full use of employees' potential, they result in excessive turnover. It poses a serious threat to the smooth functioning of hotels. Due to a limited number of research entities, the research findings cannot be generalized with regard to the whole industry. However, they can serve as the basis for a discussion on the phenomenon of human resource risk in the hotel industry and its impact on work efficiency, thus the functioning of the whole organization.
\end{abstract}

Keywords: employees; hospitality, motivating, human resources management, threats

\section{Introduction}

All decisions concerning the HR management process, bear risk. Initiative, cooperation and commitment of the whole staff are needed for the survival and development of a hotel business in an increasingly more competitive environment. The way how the personnel treat their duties depends on motivational activities undertaken by a hotel enterprise. The adjustment of motivational tools to real needs of employees is the precondition of effectiveness of these activities. Wrong decisions in terms of motivation may lead to a high employment fluctuation rate.

The objective of the article is to present an impact of staff turnover on the operation of hotel enterprises. 
Staff turnover (fluctuation) is the inflow and outflow of employees in an enterprise. In practice, the issue of employment fluctuation is still valid. Many hotel enterprises have problems not only with finding suitable employees but also with retaining them.

A theoretical part of the study is a result of the use of the desk research method. Unique entity's influence (i.e. hotel enterprise's personnel) and the executed processes of human resource management mean that human resource risk has to be assessed individually for each entity. Therefore, the author used case studies in the empirical part aiming at exemplifying human resource activities in the hotel industry. There are results from surveys and interviews with human resource managers conducted in 250 hotels in Poland.

\section{The essence and types of human resource risk}

The main problem in the functioning of modern hotel companies is the fact that there is no certainty with regard to activities. Threats that occur when conducting business activity may lead a company to bankruptcy and the list of risk factors is long and diverse. Their common characteristic is the fact that they directly affect the financial situation of an entity. By contributing to generating specific types of costs or increasing sales revenue, they imply the level of effectiveness of human resource and investment decisions which is reflected in the company's situation. Therefore, it is of great significance to identify risk factors which may affect the functioning of a given entity (Becker \& Smidt, 2016; Bhattacharya \&Wright, 2005).

One of the types of risk is human resource risk, that is the risk connected with an organization's social system. It can be defined as "involvement under conditions of uncertainty in activities concerning personnel which may prove unsuccessful" (Lipka, 2002). Exposing itself to danger, a company may significantly increase not only its chances of survival, but also its chances of development, and human capital may be enriched. Depending on speed and accuracy of the undertaken human resource activities, it can pose a threat (loss for) to or be an opportunity for business activity (Dionne, 2013; Elahi, 2013).

Human resource risk is not a homogenous category which means that many partial types of risk can be distinguished, namely (Tokarz-Kocik 2012; ):

- recruitment risk - failure to adjust labour demand and supply in quantitative and qualitative terms;

- selection risk - is a decision-making situation which involves opportunities and threats arising from employing a given person on the basis of adopted selection criteria;

- evaluation risk connected with the process of developing, formulating and expressing personal attributes, employee's behaviour at work and the results they obtain;

- risk of investment in employees' development, including: the risk of the lack of employees' willingness to develop; the risk of the lack of expenditure on human capital; the risk of leaving work by employees who the company invested in; the risk of a gap between personnel's knowledge and skills;

- motivational risk - consequences for a company resulting from a specific selection of motivational tools towards particular employees.

Human resource activities are subject to the recruitment risk arising from the changeability of phenomena in the labour market. The above phenomena build up due to the growing 
mobility of society and migration risk, and thus human resource risk becomes increasingly multidimensional and changes dynamically over time. Labour market expansion due to the Polish membership in the European Union provides more possibilities of searching an attractive job by employees and intensifies economic migration. For Polish companies, it is a challenge in terms of a growth of competitiveness which goes beyond national borders and also makes it necessary to open up to immigrants from other countries (Bizon-Górecka, 2009).

Selection risk is connected with the lack of certainty in terms of the choice of employees as people who should enrich the human resources of a hotel. Therefore, it includes a threat that instead of multiplying human capital qualitatively it will lead to its impoverishment with all related consequences.

The next function of human resource management, that is evaluation, is subject to a special risk due to difficulties with a selection of relevant evaluation techniques. Nevertheless, resigning from evaluation to not make mistakes is not a right solution as evaluation results are known to constitute a starting point for various human resource decisions. When determining the level of evaluation risk, the level of objectivity of evaluation procedures performed in a company should be taken into account.

The motivation function also involves risk. The highest risk level corresponds with obtaining a result which is the opposite of motivational activities, that is the state of employees' demotivation, despite particular expenditure on satisfying employees' needs in a better way. Leading to that may result from failure to notice the types of risk at the operational level occurring when applying specific financial and non-financial incentives. Excessive, insufficient as well as improperly targeted managers' efforts aiming at developing attitudes and behaviours of employees may be harmful. An incentive scheme should be not only consistent with the general strategy of a company (including: sub-strategy of cost development), but also compatible with the requirements of the company's environment (i.e. attracting right job candidates). Failure to meet any of the above requirements that modern incentive schemes face increases motivational risk, thus the risk of a hotel as an employer (McGee, Rennie, 2012).

\section{Nature of work and motivational activities in hotel enterprises}

A hotel enterprise consists of a team of people, as well as tangible and financial assets that form a separate entity with its own economic, technical, spatial and legal nature, and is engaged in professional business activities of offering accommodation (rooms) against payment and providing services related to it.

The work process in a hotel enterprise is of a different nature than the one found in production enterprises. This dissimilarity is mainly a result of the specific nature of hotel services as they cannot be made-to-stock, stored or delivered to clients' places of living.

Hotel services are quite specific services and providing them often poses a great challenge for hotel staff. Guests who spend longer periods of time outside home expect that many of their needs will be satisfied, i.e.:

- subsistence needs (food, hygiene, sleep),

- additional needs (entertainment, recreation, sightseeing), 
- emergency needs (medical assistance, change of plans).

Such numerous types of guests' expectations require from hotel staff to be highly available and engaged.

The simultaneity of production and consumption of services is a factor that influences the employment structure and work organization in hotel enterprises. This characteristic means that work in the hotel industry is continuous, multi-shift and includes the whole week, with Sundays and holidays. Thus, it is hard to standardize the work time and limit it to 8 hours a day. Hotels must operate 24 hours a day and, additionally, the tourism movement is intensified during the tourism season, what increases the workload of operational staff. Despite the technological development, machines cannot replace humans in the process of providing hotel services. The essence of hotel work is still a direct contact of a staff member with a tourist and this entails the necessity of employing relatively large personnel.

Attitude and predispositions of guest service employees have a decisive influence on the quality of a hotel product. Therefore, it is of a vital importance that personnel carry out their duties with the utmost engagement. This will be possible if they are properly motivated.

The basic aim of a motivation system is to stimulate people to fulfil their company missions and reach the company goals, while taking account of the needs and expectations of employees. People are motivated to work if they expect that their actions will lead to achieving a goal and getting a valuable reward - one that will satisfy their needs.

Motivating employees to work involves a range of individually personalized motivational instruments. Compensation is considered to be one of the most important and often dominating motivator. Therefore, developing a compensation structure is one of the basic processes through which motivational function is being implemented in hotel businesses. Apart from direct compensation, the effectiveness of a motivation system is determined by offered perks and benefit packages. They may include such elements as a corporate mobile phone, laptop, private health insurance, additional life insurance, coupons for free lunch in a hotel restaurant, holiday vouchers, coupons for free stay at one of hotels of the chain. Nonfinancial motivating tools also include: intangible rewards (letters of commendation, diplomas, commemorative medals and cups), in-kind rewards (albums, books with dedications) etc. These instruments are most often less expensive than financial incentives and, under some conditions, they are more effective. Creating opportunities for employees to develop their qualifications is also part of efficient motivation. As a result, it is essential to develop a comprehensive training programme that is tailored to the expectations of workers and the goals of a hotel business.

In 2019 an analysis of motivation and staff turnover in the hotel industry was conducted. The survey was aimed at hotel management staff in Poland. Managers from 250 hotels, across all sixteen voivodships, participated in this research. The largest group of survey respondents $(85 \%)$ consisted of managers from three-star hotels. The next group size-wise (12\%) managed four-star hotels. Other respondents represented one-, two- and five-star hotels. The research has shown that the majority of hotel managers see the necessity of developing staff qualifications. As many as $91 \%$ respondents said that they provide training to their workers (Fig.1). 
Figure 1: Staff motivation methods in analysed hotels in Poland

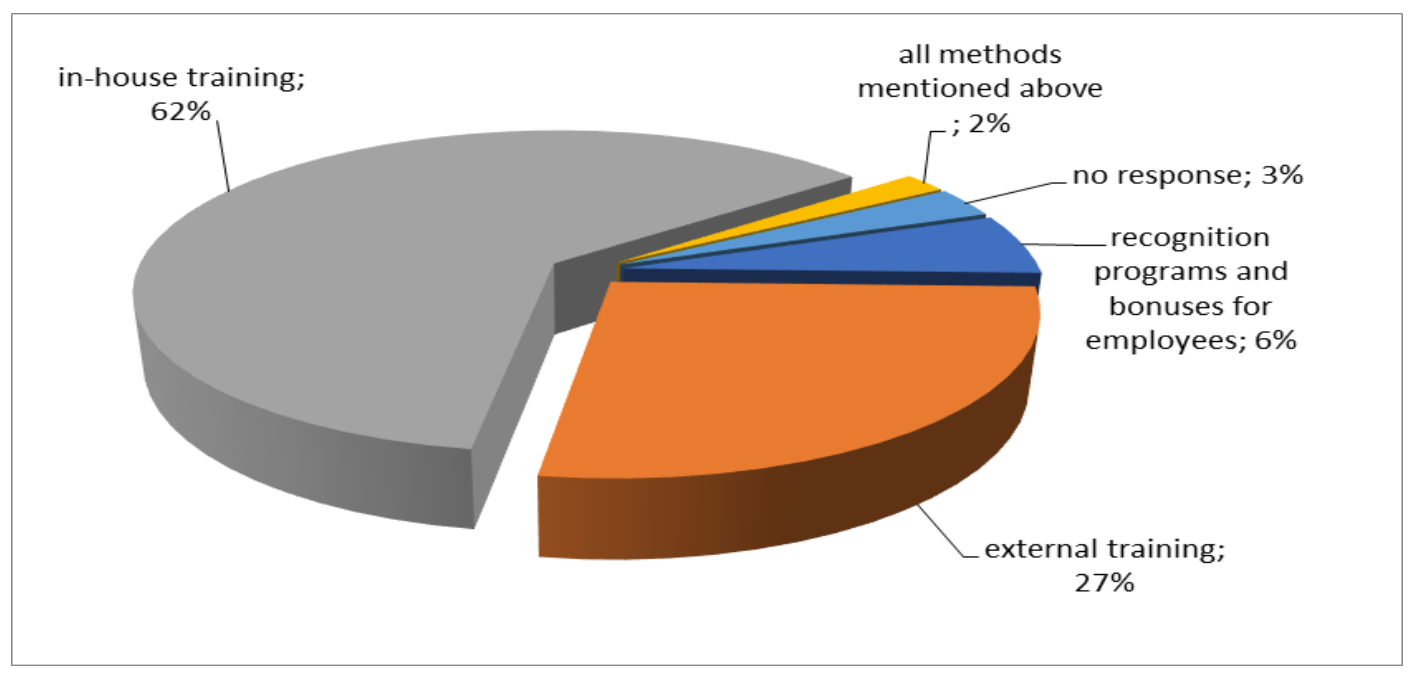

Source: own work

The fact that only $6 \%$ of the surveyed managers use employee motivation methods other than training, such as best employee programmes or bonuses, is alarming.

Tangible and intangible motivational incentives stimulate desired employee behaviours; however, their effectiveness depends mainly on how they are assessed by employees.

An improperly executed employee motivation process may lead to an ill-understood competition, feeling of unfair treatment, envy or resentment that negatively affect the work effectiveness of individuals, teams and the whole company. Mistakes in motivation can also contribute to high staff turnover in hotels.

\section{Nature and consequences of staff turnover in hotel businesses}

A high staff turnover rate is a significant problem for hotel managers. The rate at which employees resign from work varies depending on the position held (Fig. 2). 
Figure 2: Hotel departments in which the staff turnover rate is the highest

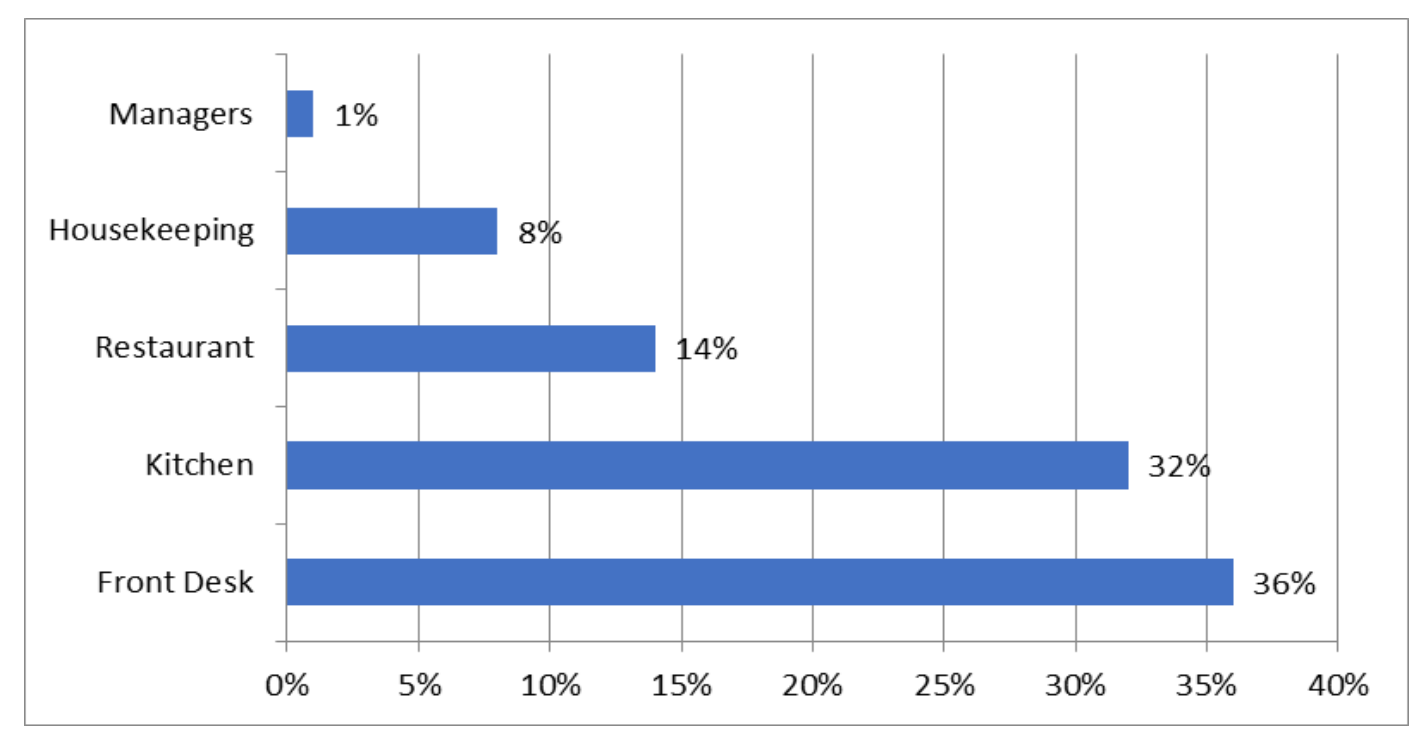

Source: own work

According to $36 \%$ respondents, a high turnover rate (over 50\%) can be most often found at the Front Desk. Other hotel departments with high staff fluctuation rates are Kitchen and Restaurant (32\% and $14 \%$ of responses, respectively). It is also quite common in hotels that housekeeping employees resign (8\% of responses). A rather high retention (loyalty) rate is observed on the managerial positions, as only $1 \%$ of the researched businesses indicated a high turnover rate in that workforce group. None of the surveyed hotels registered voluntary turnover among the administration employees.

We may look at staff fluctuation as an involuntary phenomenon, which results from legal regulations or employer's will (e.g. contract expiration, reduction in force, retirement), or a voluntary one. There are much more reasons behind voluntary resignation and they mainly depend on an individual approach of an employee or may be a sign of mistakes in the human resources management process, especially in motivating (Fig. 3.). 
Figure3: The reasons for staff turnover

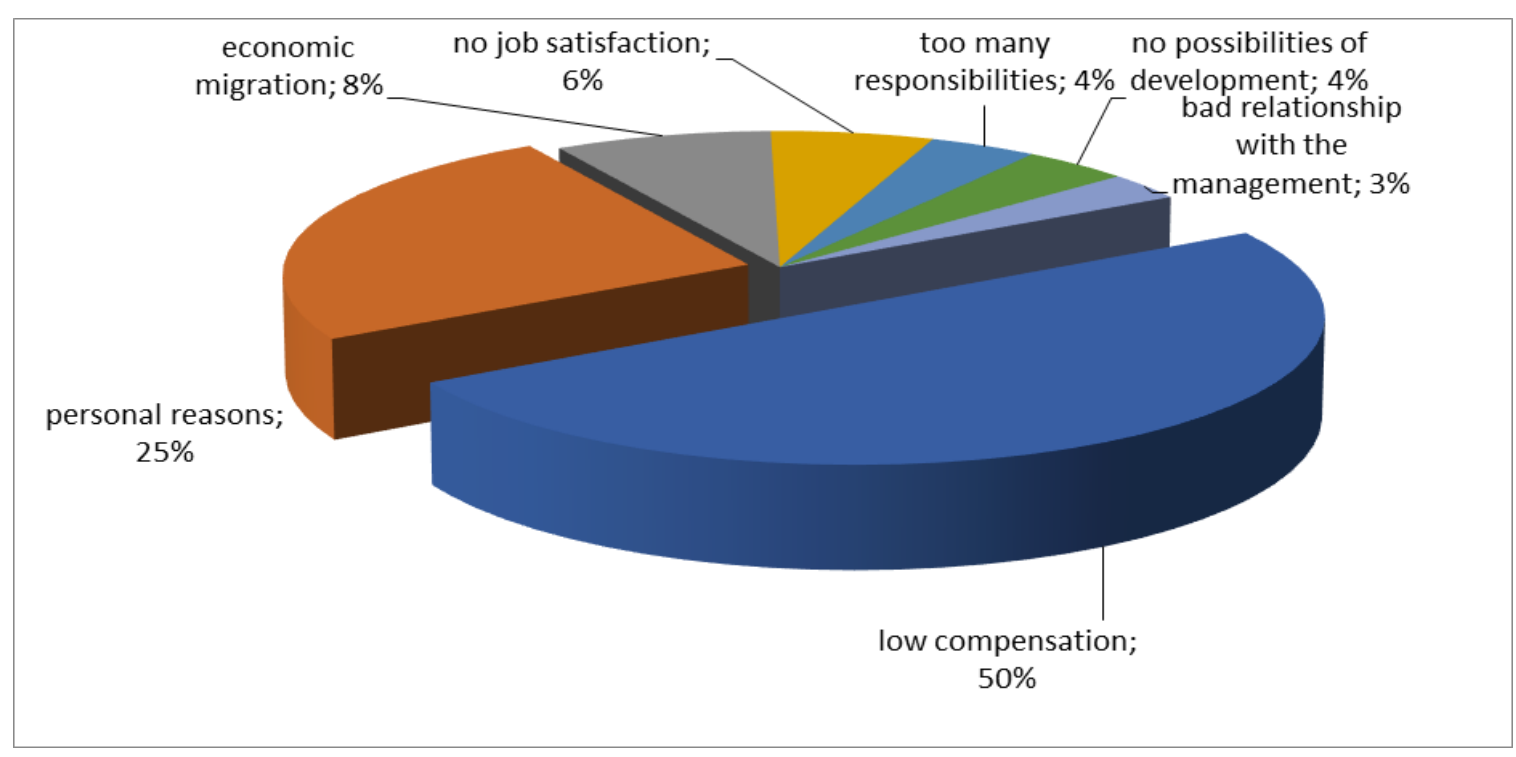

Source: own work

The research showed that the main reason behind resignation from work for $50 \%$ respondents is unsatisfactory compensation. Among other factors indicated by respondents were personal reasons, economic migration or lack of development possibilities.

Employee compensation is one of the most neglected motivational functions in hotel businesses. Salaries in the hotel industry in Poland are lower than the average ones in this economy. Median salary in the hotel industry in 2018 was PLN 3300 gross in comparison to PLN 4500 gross in the national economy (Report, 2018). In addition to the fact that salaries in the hotel industry are relatively low, one may find dysfunctional activities occurring in terms of compensation in hotel businesses. These are connected with not informing employees about the compensation methods. Other problems related to a pay policy are:

- delayed salary payment,

- disproportionately high compensation of relatives and their acquaintances in relation to workload;

- no payment for overtime.

Apart from low salaries, the research findings point to the limited promotion and career development opportunities as well as lack of respect and support from a superior as significant reasons for employees leaving a company. All of these factors demotivate and contribute to high staff fluctuation in hotel businesses.

A high staff fluctuation rate brings a range of negative consequences for a hotel business and its workforce (Taylor, 2006; Clausen \& Borg, 2010), namely:

- additional responsibilities for remaining hotel personnel,

- costs of a new recruitment and selection process,

- loss of employee's knowledge and experience for the benefit of competition,

- negative image of a hotel as an employer, 
- lower quality of service,

- loss of regular customers.

If an employee resigns from work, it reflects negatively on the hotel remaining personnel who have to deal with additional responsibilities while simultaneously carry out tasks planned earlier. Some workers see this as an opportunity to stand out, but others cannot cope with the new situation and are unhappy. It is often the case that these employees are required, irrespective to their regular responsibilities, to help with training new staff. If this only happens occasionally, the necessity of taking up additional workload does not become a problem. However, if a staff turnover rate is too high and results in an almost permanent workforce deficiency than the morale of staff may go down and they might be less engaged in their work.

The staff fluctuation phenomenon involves the need to hire new employees and this in turn means additional costs for a business. Their largest component is most often expenses related to the recruitment process, which are fees and charges for placing job advertisements in the press or work agency fee. Another element is work time cost of managers involved in the recruitment and selection process for the replacement of a departing employee. It may turn out that several job interviews have to be conducted or the Assessment Centre method have to be used in order to fill some positions. There are also costs of induction to a position and proper training of a new employee, as well as administrative costs related to introducing a new person in the organization (preparing a job contract, setting up personal files, etc.). While the abovementioned procedures are being executed, the position remains vacant. For a company, it means that productivity will be lower for a few weeks. Furthermore, workers need to be paid for overtime. That is why it is difficult to estimate a total cost of this process. The scale may vary a lot and depends on the position.

Besides generating direct costs, employment fluctuation causes loss of other resources, especially if an employee undergoes intensive training in a hotel and resigns from the position before the employer gets return on this investment. The situation is even worse when this employee resigns in order to be hired by the competition. In such a case, a hotel not only loses such resources as knowledge and experience, which an employee usually obtains at the hotel's expense, but it must also consider that they will be used by another employer to gain a competitive advantage

A high staff turnover rate is also disadvantageous for a company because of the competition on the labour market. If a hotel cannot retain employees, it will quickly gain a reputation of a bad employer. As a result, job-seeking professionals will not consider a particular hotel as a viable option in their career plan (Helm, 2011).

It should be noted that employment fluctuation may be also negatively perceived by customers. This aspect may be very important for positions which require from employees to know individual clients' needs and preferences as it has a key impact on the reputation of an organization. If staff are dismissed or changed too often in a hotel company (e.g. front desk staff, waiters, kitchen staff, masseurs), in the best case scenario, it will result in lower customer loyalty but, in the worst case, it will lead to a general opinion that the service levels are significantly lower, which in turn means a negative company image on the market. 


\section{Motivational activities limiting a staff turnover rate}

Voluntary redundancy is a symptom of lack of job satisfaction. Job satisfaction is most commonly understood as positive attitude and emotions towards the work environment and professional duties performed by a person. Research on direct relations between job satisfaction and employee behaviour allowed determining the correlation between an increase in job satisfaction and staff turnover at the level of -0.40 , which means that the increase in job satisfaction lowers a staff turnover rate (Tokarz-Kocik, 2017; Grobelna et al., 2016). Job satisfaction depends on the balance between what a person invests in their work (e.g. time, engagement), and what they receive in return (promotion, development opportunities, friendly relations), which are a motivational activities (Staples \& Higgins, 1998).

In order for them to be efficient, it is necessary that managers in a hotel recognize the employees' needs and adapt the motivation methods to them (Grobelna et al., 2016). The feedback to this will be increased employee engagement in the process of carrying out duties and staff loyalty. The main benefits of employee loyalty for a company are:

- employment retention,

- increased work efficiency,

- customer retention.

The advantage of employee loyalty is that the longer an employee works in a given company, the more work experience they gain. Staff with more experience in a hotel have a unique knowledge about the individual customer preferences or product characteristics, thus they provide better customer care. Employee loyalty also determines customer loyalty. Employment stability is significant for positions which require from employees to know individual client needs and preferences. The result of changing staff in a hotel company (e.g. receptionists, waiters, chefs, masseurs) is a gap in customer service, which leads to customer dissatisfaction and a discrepancy between the client expectations and real experience (Hill $\&$ Alexander, 2003).

Therefore, it is of the utmost importance to properly develop employee loyalty through the use of appropriate motivating stimuli. These should be adjusted to the needs and expectations of employees. A hotel should take into account that not only needs evolve due to age, new qualifications or occupied position, but also their hierarchy and the preferred method of satisfying them.

The multitude of factors that differentiate personal goals of each employee in a company requires that a company develops such a motivation system that enables all employees to fulfil their individual personal needs and simultaneously ensures that an organization reaches its own goals.

Employers have to change their approach to building relationships with employees. One solution may be to personalize the career path and replace the so-called corporate ladder with a corporate network. A corporate ladder includes traditional hierarchy, promotion path and assumes that employees' needs do not change with time. On the other hand, corporate network gives employees multiple career paths that allow them to maintain work-life balance (Grobelna \& Tokarz-Kocik, 2016). Career path personalization, which is based on an individual career development pace of an employee, gives a possibility to choose workload and work time, as well as a position and the scope of responsibilities. 


\section{Conclusion}

The presented research findings confirm that human resource activities in hotels are not always conducted properly. Instead of making full use of employees' potential, they result in excessive turnover. It poses a serious threat to the smooth functioning of hotels.

A high staff turnover rate remains one of the fundamental problems of the hotel industry. It is partly caused by a high increase in numbers of hotel businesses and demand for experienced employees. However, the main reason behind this phenomenon is not competitive enough remuneration and motivational rules applied by hotel companies.

Usually, only some general human behaviour patterns are taken into consideration when building a motivation system in a hotel company, while it is necessary to analyse many different conditions related to the characteristics of a person to whom various motivators are applied.

A variety of motivational tools may be used to influence employee engagement. It is important that they are accurately selected, tailored to the type of employee's tasks and value system and that cohesion of motivational activities is ensured, or even that they enhance each other. Employee motivation and engagement in achieving company goals is most efficient when employee and organization goals are identified. In order to increase the efficiency of a motivation system in a hotel company, it is necessary to regularly verify motivational activities connected with identifying irregularities. Therefore, hotel companies should:

- devise individual procedures for assessment of the efficiency of a motivation process,

- identify dysfunctionalities of a motivation process using the results of periodic employee evaluation,

- conduct a regular analysis of employees' expectations and aspirations.

It is obvious that employees' expectations are changing, while the principles of a motivation system are formal and are of a static nature. Therefore, the assessment of a motivation system should be conducted on a regular basis and its principles and enforcement should be adjusted by correlating them with the changing expectations of employees.

One should remember that there are differences between employees in terms of their qualifications and engagement within each company. That is why the repercussions of their resignation from work may vary. Some people can be easily and cheaply replaced, while others are difficult to replace, especially if the same level of efficiency is to be achieved. For that reason, each group of employees should be treated differently. Motivational activities should be focused on employees that possess extensive professional knowledge and whose resignation may cause most problems for an organization and generate high costs.

Due to a limited number of research entities, the article involves the analysis of the case study. Therefore, the research findings cannot be generalized with regard to the whole industry. However, they can serve as the basis for a discussion on the phenomenon of human resource risk in the hotel industry and its impact on work efficiency, thus the functioning of the whole organization. 


\section{Acknowledgment}

The project is financed within the framework of the program of the Minister of Science and Higher Education under the name "Regional Excellence Initiative" in the years 2019 - 2022; project number 001/RID/2018/19; the amount of financing PLN $10,684,000.00$.

\section{References}

[1.]Becker, K., \& Smidt, M. (2016). A risk perspective on human resource management: A review and directions for future research. Human Resource Management Review, 26(2), 149-165.

[2.]Bhattacharya, M., \&Wright, P.M. (2005). Managing human assets in an uncertain world: Applying real options theory to HRM. International Journal of Human Resource Management, 16(6), 929-948.

[3.]Bizon- Górecka, J. (2009), Migracje ludności jako czynnik wzrostu ryzyka personalnego w przedsiębiorstwie. [in] A. Lipka, S. Waszczak (Ed.), Koszty jakości zarządzania kapitałem ludzkim a ryzyko personalne. Katowice: Prace Naukowe Akademii Ekonomicznej w Katowicach.

[4.]Clausen, T., \& Borg, V. (2010). Do positive work-related states mediate the association between psychosocial work characteristics and turnover? A longitudinal analysis. International Journal of Stress Management, 17(4), 308-324.

[5.]Dionne, G. (2013). Risk management: History, definition, and critique. Risk Management and Insurance Review, 16(2), 147-166.

[6.]Elahi, E. (2013). Risk management: The next source of competitive advantage. Foresight: the Journal of Futures Studies, Strategic Thinking and Policy, 15(2), 117131.

[7.]Grobelna, A., \& Tokarz-Kocik, A. (2016, September). Work-life balance and its importance for the work process in hospitality industry. A perspective of generation $\mathrm{Y}$ employees. In Economic and Social Development (Book of Proceedings), 16th International Scientific Conference on Economic and Social (p. 489).

[8.]Grobelna, A., Sidorkiewicz, M., \& Tokarz-Kocik, A. (2016). Job satisfaction among hotel employees: analyzing selected antecedents and job outcomes. a case study from Poland.

[9.]Helm, S. (2011). Employees' awareness of their impact on corporate reputation. Journal of Business Research, 64(7), 657-663.

[10.] Hill, N., Alexander, J. (2003). Pomiar satysfakcji i lojalności klientów, Publishing House Oficyna Ekonomiczna, Kraków 2003

[11.] Lipka, A. (2002). Ryzyko personalne: szanse i zagrożenia zarządzania zasobami ludzkimi. Poltext, Warszawa.

[12.] McGee, R., Rennie, A. (2012). Budowanie zaangażowania pracowników. Warszawa: ABC a Wolters Kluwer business

[13.] Report 2018: Internet Salary Survey. Survey of hotel, catering and tourism industries; Available: $\quad$ https://wynagrodzenia.pl/artykul/podsumowanieogolnopolskiego-badania-wynagrodzen-w-2018-roku 
[14.] Staples, D. S., \& Higgins, C. A. (1998), A Study of the Impact of Factor Importance Weightings on Job Satisfaction Measures. Journal of Business and Psychology 1998, No 13.

[15.] Taylor, S. (2006). Ptynność zatrudnienia. Jak zatrzymać pracowników $w$ firmie, Publishing House Wolters Kluwer Polska, Kraków.

[16.] Tokarz-Kocik, A. (2012). Personel jako jedno ze źródeł ryzyka w przedsiębiorstwie hotelarskim. Zeszyty Naukowe Uniwersytetu Szczecińskiego. Ekonomiczne Problemy Turystyki, (1 (17)), 57-63.

[17.] Tokarz-Kocik, A. (2017). Ryzyko motywacyjne $w$ gospodarowaniu kapitałem ludzkim $w$ hotelarstwie. Ujęcie ekonomiczne, Szczecin: Wydawnictwo Naukowe Uniwersytetu Szczecińskiego. 